- Water is an important vehicle for fluoride and knowing the amount of fluoride ingested from fluoridated water is important for general and dental health.

- There is very little information on water intake in this country and world-wide. This study shows that water intake is less than commonly assumed. The present data show water intake to be similar to levels reported 20 years ago, but lower than some other countries.

- There has been a shift in the last 20 years to greater consumption of soft drinks and less consumption of milk and tea, in English adolescents.

\title{
Changes in water intake of Northumbrian adolescents 1980 to 2000
}

\author{
F. V. Zohouri, ${ }^{1}$ A. J. Rugg-Gunn, ${ }^{2}$ E. S. Fletcher, ${ }^{3}$ A. F. Hackett, ${ }^{4}$ P. J. Moynihan, ${ }^{5}$ J. C. Mathers, ${ }^{6}$ and A. J. Adamson ${ }^{7}$
}

\begin{abstract}
Objectives To determine: total water intake in young English adolescents; the relative importance of sources of water intake; and changes in water intake and sources of water between 1980 and 2000. Design A cross-sectional observational study of the diets of 11-12year-old children attending seven schools in south Northumberland, UK. The information obtained was compared with results from a similar survey carried out 20 years previously.

Methods All children attending these schools were invited to participate. They completed a three-day diet diary with an interview on the fourth day, on two occasions during the school year. Standard UK food composition tables were used and water intake from various sources calculated. Anthropometric and social class information was obtained.

Results Four hundred and twenty-four children completed all aspects of the study (64\% of those eligible). The mean total water intake was $1,130 \mathrm{~g} \mathrm{~d}^{-1}$, approximately the same as that recorded 20 years before. Water intake in relation to energy intake: water intake was $139 \mathrm{~g} \mathrm{MJ}^{-1}$ in boys and $143 \mathrm{~g} \mathrm{MJ}^{-1}$ in girls. Sixty-five per cent of water came from drinks and 35\% from foods; very similar to proportions 20 years before. The sources of water in drinks had changed considerably, with a marked increase in consumption of soft drinks (especially carbonated drinks) and a decrease in consumption of hot drinks and milk. There were a few differences between sexes but little difference between social groups. Conclusions Total water intake was similar to that recorded 20 years previously and lower than intakes reported in other countries. Changes in the sources of water meant that less water consumed was likely to come from the tap in the house and more from drinks made elsewhere, than 20 years previously. These changes have implications for estimating fluoride intake in fluoridated areas.
\end{abstract}

${ }^{1}$ Research Associate, ${ }^{2}$ Professor Emeritus, ${ }^{5 *}$ Senior Lecturer in Nutrition, School of Dental Sciences, Newcastle University, Framlington Place, Newcastle upon Tyne NE2 4BW and Human Nutrition Research Centre, Newcastle University, Wellcome Research Laboratories, Royal Victoria Infirmary, Queen Victoria Road, Newcastle upon Tyne NE1 4LP: ${ }^{4}$ Reader in Community Nutrition, John Moores University, Liverpool, L17 6BD; ${ }^{3}$ Research Associate, ${ }^{6}$ Professor of Human Nutrition, ${ }^{7}$ Lecturer in Nutrition, Human Nutrition Research Centre, School of Clinical Medical Sciences, Newcastle University, Wellcome Research Laboratories, Royal Victoria Infirmary, Queen Victoria Road, Newcastle upon Tyne NE1 4LP.

${ }^{*}$ Correspondence to: Dr P. Moynihan, School of Dental Sciences, Newcastle University, Framlington Place, Newcastle upon Tyne, NE2 4BW

Email:P.J.Moynihan@newcastle.ac.uk

\section{Refereed paper}

Received 07.02.03; Accepted 19.06.03

doi:10.1038/sj.bdj.4811226

$\odot$ British Dental Journal 2004; 196: 547-552

\section{INTRODUCTION}

The ingestion of water is essential for life, yet it is frequently omitted from discussion of optimum nutrition, probably because ready access to drinking water is seldom difficult or expensive in developed countries such as the UK. Drinking water is recognised as a significant vehicle for essential minerals and/or undesirable contaminants and the amount of these consumed will depend on their concentration in water and the quantity of water consumed. Drinking water is a well-known vehicle for dietary fluoride, leading to benefits when the concentration is optimal, defluoridation when fluoride concentration in water is too high, and addition of fluoride when the concentration is too low and when the severity of dental caries in the community warrants it. ${ }^{1}$ Drinking water can also be a significant source of dietary calcium, and a recent innovation has been the addition of calcium to some bottled waters and soft drinks. ${ }^{2}$

Despite being essential for life and a vehicle for mineral nutrients, there is surprisingly little information on water intake of children and adolescents - an important time of growth. The need for more information on fluoride intake, particularly in children, was highlighted in a recent report by the UK Medical Research Council: ${ }^{3}$ measurement of total fluoride intake and the relative importance of different sources of fluoride ingestion requires measurement of water intake. The largest and most recent survey of the diets of British children (the National Diet and Nutrition Survey, or NDNS) conducted in $1997^{4}$ reported the consumption of several fluids, such as drinking water (bottled and tap water), milk, fruit juices, other soft drinks and alcoholic drinks. However, total water was not reported. For boys aged 11-14 years, mean intake of drinking water was $91 \mathrm{~g} \mathrm{~d}^{-1}$, and for girls $105 \mathrm{~g} \mathrm{~d}^{-1}$.

A comprehensive study of water intake in a sample of British children was undertaken in $1980 ; ;^{5}$ this included a discussion of earlier estimates of water intake and noted that the quantity of drinking (or tap) water recorded in 1980 was much lower than previous estimates. While it was generally assumed previously that about one litre of tap water was drunk by children per day (and if fluoridated to $1 \mathrm{mg} \mathrm{l}^{-1}$, would result in ingestion of $1 \mathrm{mg}$ fluoride per day from this source), this study reported a mean intake of 616 $\mathrm{g} \mathrm{d}^{-1}$ of water from public water supplies.

Eating and drinking habits of children have changed. Soft drink consumption in the USA and Canada has doubled over the last 30 years, with a decline of similar magnitude in tap water consump- 
tion. ${ }^{6-9}$ In the UK, soft drink consumption has increased from 151 litres in 1990 to 200 litres per person per year in $2000 .{ }^{10}$ A recent survey of young children in Southampton, UK, suggested that only about a quarter drank 'plain water."11 Surveys in many countries, including the UK, have shown a decrease in milk consumption by children. ${ }^{4,5,9,12}$

Since our report in $1980^{5}$, two studies in the USA ${ }^{8,9}$ and one in Germany ${ }^{12}$ measured and reported water intake. Using data collected in the American Country Survey of Food Intake by Individuals (CSFII) in 1994-96, Heller et al. ${ }^{8}$ reported that the mean total water intake in 11-19-year-olds was 2.27 litres per day and 'drinking water' was $715 \mathrm{~g} \mathrm{~d}^{-1}$. Sohn et al. ${ }^{9}$ examined data from the American NHANES III survey (1988-94) and reported that total fluid intake in young children (1-10 years, mean 5.5 years) was $1,736 \mathrm{~g} \mathrm{~d}^{-1}$, with 'plain water' a mean of $609 \mathrm{~g} \mathrm{~d}^{-1}$. Data collected in Dortmund, Germany (the DONALD study ${ }^{12}$ ) between 1985 and 1999, revealed that total water intake in boys aged 9-13 years was $1,891 \mathrm{~g} \mathrm{~d}^{-1}$ and $1,676 \mathrm{~g} \mathrm{~d}^{-1}$ in girls. Estimates of metabolic water were included in these figures - for example, in boys, 36\% of water came from foods, 51\% from drinks and 13\% from metabolism.

Our survey in $1980^{5}$ involved 405 11-12-year-old young English adolescents. In 2000, a similar study was undertaken of children of the same age attending the same schools, with dietary information obtained in the same way. Because of the importance of information on water intake and sources of dietary water intake in children, and the paucity of information on this subject, data from the 2000 survey were analysed with the aims of reporting: (a) total water intake in young English adolescents in 2000, (b) the relative importance of sources of water intake, particularly the amount from public water supplies, and (c) changes in water intake and sources of water in young adolescents between 1980 and 2000.

\section{METHOD}

The study was conducted in seven middle schools in south Northumberland: these were the same schools that participated in the study in 1980. The study protocol was approved by the Local Research Ethics Committee, and the County Education Authority approved access to the schools. Parents or guardians of all children in year 7 (aged 11-12 years) were invited to give informed written consent to their child participating in the study which took place between October 1999 and July 2000.

Dietary information was obtained from each participating child using a self-completion three-day diet record with private interview with the study nutritionist on the fourth day. ${ }^{13}$ This was repeated, giving six days' record per child, with the first diary being completed between October and February, and the second diary between March and July. Six different days of the week were chosen for each child, who received full instructions on how to complete the diary, as a group and individually at the time of issue. Information recorded was: time of day the food was consumed, what the food was, and how much was eaten or drunk in household measures. At interview after completion of the diary, the type of food/drink and the quantities consumed were clarified using photographs, calibrated cups, bowls, spoons etc. and food models.

Data were entered into an electronic database, and energy and nutrient values calculated using standard UK food composition tables - McCance and Widdowson's The composition of foods and supplements. ${ }^{14-22}$ Some additional food composition information was obtained from food manufacturers. Foods and drinks were categorised into groups (Table 1) to determine the sources of dietary water: the groups were the same as those reported for the 1980 study $^{5}$ to allow comparison. They fell into two broad categories: foods and drinks. Soups were classed as foods. For noncarbonated soft drinks, the water content of the concentrated juice was included in the non-carbonated soft drinks group and the water added to dilute it was included in the water group. For carbonated drinks and for infusions of tea and coffee, the water content was included within these groups. Milk in puddings was classed as a food and excluded from the milk group. The water content of soups, rice and pasta were as prepared for eating. The amount of 'consumer-added' water was estimated by summing the water content of groups: water as such, hot drinks made with water, and rice and pasta. The amount of 'manufacturer-added' water was estimated by adding the water content of carbonated, non-carbonated soft drinks and water added to ready-to-

Table 1 Daily water intake presented as mean $\left(\mathrm{g} \mathrm{d}^{-1}\right)$, SD, 5 and 95 percentiles and as per cent of total intake, by study, for 11-12-year-old Northumbrian adolescents. These data were calculated using each subject's mean daily intake: the mean of 6 days in 2000 and 15 days in 1980.

\begin{tabular}{|c|c|c|c|c|c|c|c|c|c|c|}
\hline \multirow{4}{*}{$\begin{array}{l}\text { Study: year } \\
\text { No of subjects }\end{array}$} & \multicolumn{5}{|c|}{2000} & \multicolumn{5}{|c|}{1980} \\
\hline & \multicolumn{5}{|c|}{424} & \multicolumn{5}{|c|}{405} \\
\hline & \multicolumn{5}{|c|}{ Percentiles } & & \multicolumn{4}{|c|}{ Percentiles } \\
\hline & Mean & SD & 5 & 95 & $(\%)^{*}$ & Mean & SD & 5 & 95 & $(\%)^{*}$ \\
\hline \multicolumn{11}{|l|}{ Dietary sources: } \\
\hline All drinks & 738 & 280 & 359 & 1,226 & 65 & 841 & 214 & 513 & 1,227 & 66 \\
\hline Water & 225 & 202 & 35 & 571 & 20 & 176 & 133 & 23 & 469 & 14 \\
\hline Hot drinks & 93 & 124 & 25 & 371 & 8 & 336 & 226 & 6 & 741 & 26 \\
\hline Tea & 68 & 110 & 25 & 365 & 6 & 214 & 204 & 0 & 641 & 16 \\
\hline Coffee and others & 25 & 55 & 18 & 229 & 2 & 121 & 148 & 0 & 426 & 9 \\
\hline Soft drinks & 291 & 171 & 45 & 578 & 26 & 109 & 80 & 17 & 250 & 9 \\
\hline Carbonated & 191 & 151 & 33 & 467 & 17 & 78 & 75 & 0 & 208 & 6 \\
\hline Non-carbonated & 32 & 41 & 6 & 109 & 3 & 22 & 23 & 0 & 68 & 2 \\
\hline Fruit juice & 70 & 89 & 15 & 251 & 6 & 9 & 18 & 0 & 45 & 1 \\
\hline Milk & 128 & 90 & 26 & 310 & 11 & 219 & 119 & 55 & 444 & 17 \\
\hline All foods & 392 & 118 & 214 & 626 & 35 & 418 & 98 & 278 & 588 & 34 \\
\hline Vegetables & 129 & 59 & 47 & 241 & 11 & 131 & 49 & 60 & 223 & 11 \\
\hline Fruit & 34 & 40 & 5 & 120 & 3 & 44 & 33 & 3 & 108 & 4 \\
\hline Soups and gravy & 17 & 24 & 4 & 79 & 2 & 42 & 31 & 3 & 105 & 3 \\
\hline Rice and pasta & 45 & 40 & 8 & 125 & 4 & 4 & 6 & 0 & 18 & 0 \\
\hline Other & 167 & 61 & 78 & 278 & 15 & 198 & 53 & 125 & 292 & 16 \\
\hline All sources & 1,130 & 329 & 665 & 1,727 & 100 & 1,259 & 245 & 892 & 1,676 & 100 \\
\hline Consumer-added & 401 & 229 & 124 & 765 & 35 & 515 & 201 & 189 & 871 & 40 \\
\hline Manufacturer-added & 274 & 165 & 67 & 578 & 24 & 101 & 76 & 15 & 232 & 8 \\
\hline
\end{tabular}


Table 2 Daily water intake presented as mean $\left(\mathrm{g} \mathrm{d}^{-1}\right)$, SD, and as per cent of total intake, by study and sex, for 11-12-year-old Northumbrian adolescents.

\begin{tabular}{|c|c|c|c|c|c|c|c|c|c|c|c|c|}
\hline \multirow{2}{*}{$\begin{array}{l}\text { Study: year } \\
\text { Sex }\end{array}$} & \multicolumn{6}{|c|}{2000} & \multicolumn{6}{|c|}{1980} \\
\hline & \multirow{2}{*}{\multicolumn{3}{|c|}{$\begin{array}{r}\text { Males } \\
(196)\end{array}$}} & \multirow{2}{*}{\multicolumn{3}{|c|}{$\begin{array}{l}\text { Females } \\
(228)\end{array}$}} & \multirow{2}{*}{\multicolumn{3}{|c|}{$\begin{array}{r}\text { Males } \\
(193) \\
\end{array}$}} & \multirow{2}{*}{\multicolumn{3}{|c|}{$\begin{array}{r}\text { Females } \\
(212) \\
\end{array}$}} \\
\hline \multirow[t]{2}{*}{ (No of children) } & & & & & & & & & & & & \\
\hline & Mean & SD & $(\%)^{*}$ & Mean & SD & $(\%)^{*}$ & Mean & SD & $(\%)^{*}$ & Mean & SD & $(\%)^{*}$ \\
\hline \multicolumn{13}{|l|}{ Dietary sources: } \\
\hline All Drinks & 778 & 310 & 66 & 703 & 246 & 65 & 876 & 209 & 66 & 809 & 213 & 66 \\
\hline Water & 223 & 239 & 19 & 227 & 163 & 21 & 171 & 126 & 13 & 181 & 139 & 15 \\
\hline Hot drinks & 83 & 113 & 7 & 101 & 132 & 9 & 342 & 235 & 25 & 330 & 217 & 26 \\
\hline Tea & 56 & 91 & 5 & 78 & 124 & 7 & \# & \# & $\#$ & $\#$ & $\#$ & $\#$ \\
\hline Soft drinks & 321 & 178 & 27 & 267 & 153 & 25 & 111 & 85 & 9 & 107 & 74 & 9 \\
\hline Carbonated & 217 & 165 & 19 & 166 & 133 & 15 & \# & \# & $\#$ & \# & \# & $\#$ \\
\hline Milk & 148 & 102 & 13 & 109 & 73 & 10 & 251 & 130 & 19 & 190 & 100 & 16 \\
\hline All foods & 400 & 125 & 34 & 385 & 112 & 35 & 438 & 102 & 34 & 400 & 90 & 34 \\
\hline All sources & 1,178 & 360 & 100 & 1,088 & 294 & 100 & 1,315 & 238 & 100 & 1,209 & 241 & 100 \\
\hline Consumer-added & 387 & 255 & 33 & 413 & 204 & 38 & 517 & 208 & 39 & 515 & 196 & 42 \\
\hline Manufacturer-added & 311 & 183 & 26 & 242 & 141 & 22 & 104 & 84 & 8 & 97 & 69 & 8 \\
\hline
\end{tabular}

eat/drink foodstuffs by manufacturers such as soups and canned fruits in syrup.

An estimate of the validity of the dietary survey method will be published, ${ }^{13}$ based upon the ratio of recorded energy intake to estimated basal metabolic rate for this age-group. An estimate of the reliability of data collected in this way has been published. ${ }^{23}$

The occupations of each child's parents were used to classify the subjects into 'high', 'middle', 'low' and 'unclassified' social groups. The national system of classifying parental occupation had changed substantially since our survey in 1980. Because it was desirable to compare social groups, the Occupational Information Unit of the Office of National Statistics classified parental occupation (the 'higher' code for both parents, if available) in the present study using the Simplified Social Class based on the Standard Occupational Classification 1990. ${ }^{24}$

The mean intakes for six days were calculated for each child. Descriptive data are presented as means, standard deviations and 5 and 95 percentiles. Statistical analysis investigated the effect of sex and social group, by analysis of variance. The 1980 data were as published, ${ }^{5}$ which was the mean of 15 days' intake recorded for each child.

\section{RESULTS}

In the 2000 survey, 450 (68\%) of the 661 eligible children in the seven schools volunteered to participate; of these, 94\% (424) completed all aspects. Reasons for non-compliance are given in the main report. ${ }^{13}$ Using postcode information, available for $96 \%$ of all children, the social profile of those who completed the study was not statistically significantly different $(p=0.09)$ from that for all eligible children. ${ }^{13}$ Forty-six per cent of the 424 children were boys. The percentage of children in 'high', 'middle' and 'low' social groups in 2000 was $47 \%, 28 \%$ and $14 \%$, respectively, with $11 \%$ unclassified. In 1980, the comparable percentages were 21\%, 43\% and $29 \%$. All days of the week were represented, with $68 \%$ of the dietary information being recorded on schooldays: the profile of the days surveyed was similar in both surveys. ${ }^{13}$

All children were from school year 7 and their mean age at the mid-point of the 2000 study was 11 years 11 months. In the 1980 study, the corresponding age was 12 years 5 months, since this study lasted one year longer than the 2000 study. In 2000, the mean weights of the children were: boys $45.4 \mathrm{~kg}$, girls $46.6 \mathrm{~kg}$; their mean energy intakes were: boys $8.45 \mathrm{MJ}$, girls 7.60 MJ. The corresponding figures for the first year of the 1980 study were: boys $39.2 \mathrm{~kg}$, girls $39.9 \mathrm{~kg}$; boys $8.90 \mathrm{MJ}$, girls 8.27 MJ. The ratio of measured energy intake to predicted basal metabolic rate was 1.38 in 2000 and 1.49 in 1980 , for all children. ${ }^{13}$ The reliability of recorded data in the 1980 study was 0.78 for 15 days' record and 0.59 for 6 days' record. ${ }^{23}$

In 2000, the mean total water intake was $1,130 \mathrm{~g}$ (Table 1); $1,178 \mathrm{~g}$ in boys and 1,088 $\mathrm{g}$ in girls (Table 2). In relation to body weight, total water intake was $25.95 \mathrm{~g} \mathrm{~kg}^{-1}$ in boys and $23.35 \mathrm{~g} \mathrm{~kg}^{-1}$ in girls. Relative to energy intake, total water intake was $139 \mathrm{~g} \mathrm{MJ}^{-1}$ (0.58 $\left.\mathrm{g} \mathrm{kcal}^{-1}\right)$ in boys and $143 \mathrm{~g} \mathrm{MJ}^{-1}\left(0.60 \mathrm{~g} \mathrm{kcal}^{-1}\right)$ in girls. Analysis of variance for the 2000 survey data revealed that the difference in total water intake between boys and girls was statistically significant $(\mathrm{p}<0.01)$ but that differences between social groups were not significant - data for each social grouping are, therefore, not given. Total water intake had fallen slightly between 1980 and 2000 in both boys and girls (Tables 1 and 2).

The proportions of water obtained from drinks and foods $(65 \%$ and 35\%, respectively) in 2000 were similar to proportions in 1980 (Table 1). Within foods, there was little difference in the proportion of water coming from various sources, although rice and pasta were more important sources in 2000. Within drinks, marked changes were seen. Water from hot drinks had declined markedly and milk consumption had also decreased. In contrast, consumption of soft drinks, especially carbonated drinks, had increased substantially, and consumption of 'water' (which could have been obtained from tap water by itself, bottled water or from water to dilute squashes in the home) had also increased. Carbonated soft drink consumption reached $191 \mathrm{~g} \mathrm{~d}^{-1}$ in 2000 in these young adolescents. Of the $225 \mathrm{~g} \mathrm{~d}^{-1}$ of 'water' drunk per day, $135 \mathrm{~g}(\mathrm{sd}=187)$ was tap water by itself or bottled water, and the remaining $90 \mathrm{~g} \mathrm{~d}^{-1}$ was used to dilute squash - this subdivision was not available in 1980. The high standard deviation in relation to the mean, implies a skewed distribution: distributions of the subjects are considered below (Figure 1).

Consumer-added water was estimated to be $401 \mathrm{~g} \mathrm{~d}^{-1}$ in 2000; providing $35 \%$ of total water intake (Table 1). This was lower than the estimate in 1980 of $515 \mathrm{~g} \mathrm{~d}^{-1} ; 40 \%$ of total water intake. In contrast, the estimate for manufacturer-added water more than doubled, from $101 \mathrm{~g} \mathrm{~d}^{-1}$ in 1980 to $274 \mathrm{~g} \mathrm{~d}^{-1}$ in 2000, providing $24 \%$ of total water intake.

When added together, consumer-added and manufacturer-added water provides an estimate of water coming from public water supplies - the former coming from the subject's home and the latter from wherever the canned or bottled product was manufactured. In 2000 , this combined figure was $675 \mathrm{~g} \mathrm{~d}^{-1}$ (59\% of total water intake), somewhat higher than $616 \mathrm{~g} \mathrm{~d}^{-1}$ recorded in 1980. The distributions of the 424 subjects in 2000 according to their mean (of 6 days) total 
Fig 1 Percentage frequency distribution of intakes of total water and of water from different sources by 424 Northumbrian adolescents in 2000 :

a) Mean daily total water intake $\left(\mathrm{kg} \mathrm{d}^{-1}\right)$. Data presented are means of 6 days per

child.

b) Mean daily intake of consumer- and manufacturer-added water $\left(\mathrm{kg} \mathrm{d}^{-1}\right)$. Data presented are means of 6 days per child.
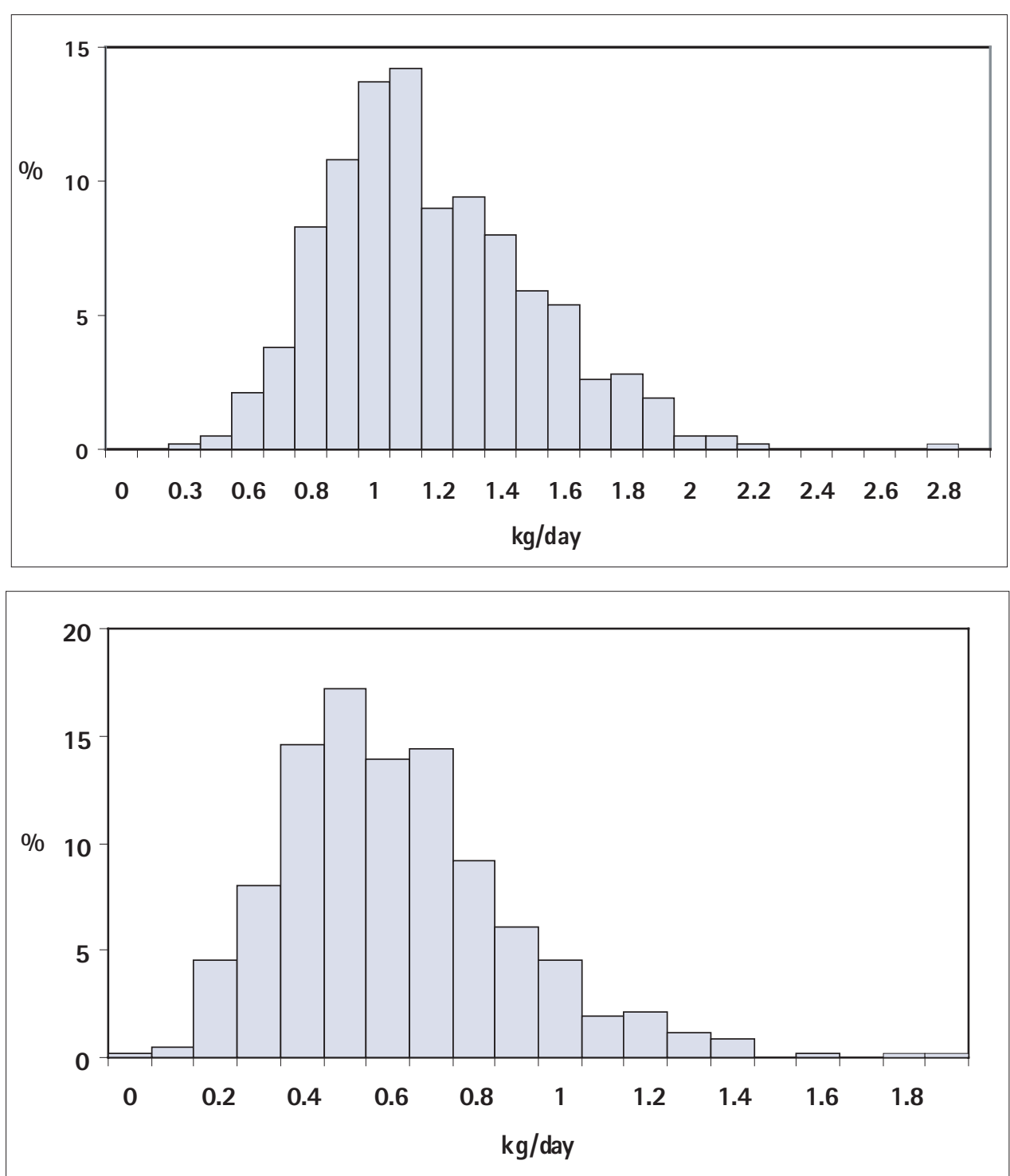

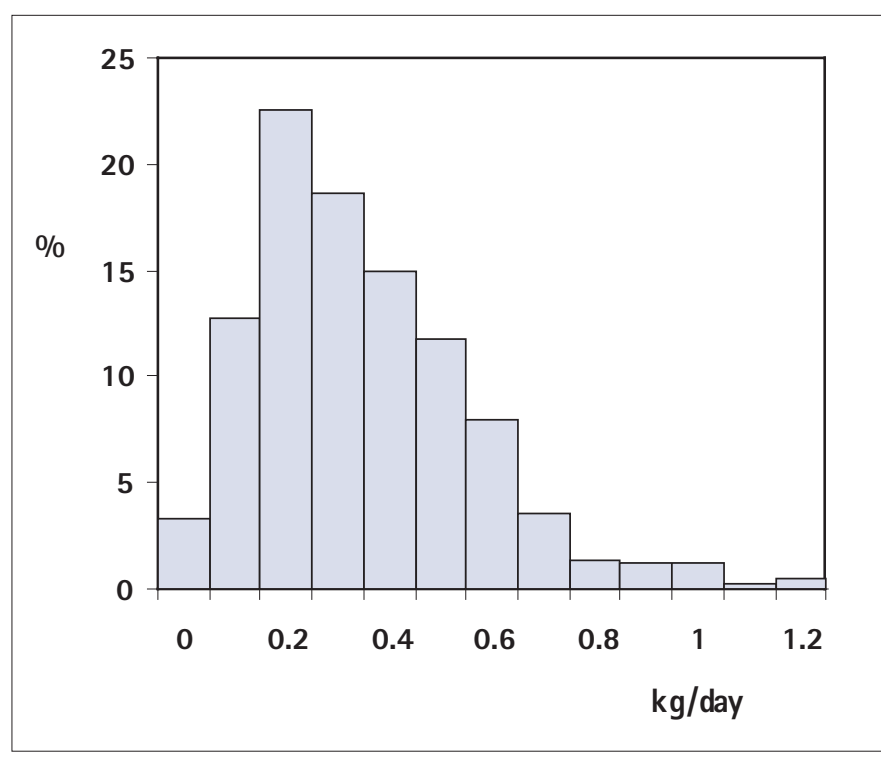

c) Mean daily intake of consumer-added water alone $\left(\mathrm{kg} \mathrm{d}^{-1}\right)$. Data presented are means of 6 days per child.

water intake, consumer-added plus manufacturer-added water, and consumer-added water alone, are given in Figure 1. These can be compared with distributions for the 1980 study published previously (means of 15 days). ${ }^{5}$ Over the 6 days recorded, just over 39\% of sub- jects ingested less than one litre of water (total water) per day (Figure 1a). As shown in Figure 1b, 10\% were likely to have consumed over one litre of water from public water supplies per day, and less than $1 \%$ over $1.5 \mathrm{l} \mathrm{d}^{-1}$ from this source. About 32\% of subjects had intakes between 0.4 and $0.6 \mathrm{l} \mathrm{d}^{-1}$. The proportion of subjects ingesting over one litre per day from their household supply (Figure 1c) was only $2 \%$, with $57 \%$ consuming less than $0.4 \mathrm{l} \mathrm{d}^{-1}$.

There were some small differences in consumption patterns for boys and girls (Table 2). Tea consumption tended to be higher in girls, while carbonated soft drink and milk consumption tended to be higher in boys. This sex difference for milk consumption was also observed in 1980. The changes in consumption of consumer-added and manufacturer-added water between 1980 and 2000, noted above, were similar for boys and girls, providing 59\% and 60\% of total water, respectively (Table 2) in 2000, although a greater proportion was manufacturer-added water in boys (largely carbonated soft drinks) and consumer-added water in girls (largely hot drinks).

\section{DISCUSSION}

The main finding of the study was that total water intake, excluding metabolic water, in a group of young adolescent English children was $1.13 \mathrm{l} \mathrm{d}^{-1}$; approximately the same as that recorded for similarly-aged children attending the same schools twenty years previously. ${ }^{5}$ The proportion of water coming from drinks (65\%) and from foods (35\%) were also almost unchanged from those recorded in the previous survey. However, the sources of water 
from drinks had changed considerably. Soft drink consumption had increased from a mean of $109 \mathrm{~g} \mathrm{~d}^{-1}$ to $291 \mathrm{~g} \mathrm{~d}^{-1}$, most of this increase being due to carbonated drinks. Conversely, there had been a marked decrease in consumption of hot drinks (from a mean of $336 \mathrm{~g} \mathrm{~d}^{-1}$ to $93 \mathrm{~g} \mathrm{~d}^{-1}$ ) and milk (from 219 to $128 \mathrm{~g} \mathrm{~d}^{-1}$ ). These changes resulted in an increase in manufacturer-added water (from $8 \%$ to $24 \%$ of total water) and a decrease in consumeradded water (from $40 \%$ to $35 \%$ of total water). There were a few differences between boys and girls but no important differences between social groups.

The study in 2000 was conducted in the same seven Northumberland schools using the same methods of collecting dietary information as in the study 20 years previously. It was a local survey, but the nutritional intake recorded for these children has been found to be similar to data recorded in the national survey. ${ }^{4}$ Sixtyfour per cent of eligible children completed all aspects of the study (compared with 51\% in 1980): there was a tendency for the more deprived not to participate but this difference did not reach statistical significance.

Measurement of dietary intake is difficult. A common way of validating intake is to examine the ratio of recorded energy intake to estimated basal metabolic rate. This value was 1.38 in 2000 (1.49 in 1980). While energy expenditure through exercise may well have fallen over 20 years, the possibility of under-recording remains and is discussed elsewhere. ${ }^{13}$ It should be realised that the above are estimates of validity of energy intake; it would be extremely difficult to estimate the validity of water intake. As discussed previously, every effort was made to encourage the children to record every intake - 'even a glass of water. ${ }^{5}$ The more days recorded per subject, the higher the reliability of the dietary data. The previous estimates put the reliability of 6 days' record ( 2 surveys of 3 days each) at 0.59 - this can be compared with a value of 0.26 for one days' record and 0.78 for 5 surveys of 3 days each. ${ }^{23}$ This implies fairly large within-subject between-days variation. Because of this, the distributions in Figure 1 in particular, need to be viewed with caution (the distributions would have been narrower if more days per subject had been recorded). This issue was discussed more fully in the previous paper ${ }^{5}$ and in a recent report on fluoride intake, ${ }^{3}$ since there are important implications in the interpretation of intake for the outliers in the distribution.

The 1980 study lasted one year longer than the 2000 study so that the mean age of the children at the mid-point of the survey was six months different. While water intake increases with age in children and adolescents, it is unlikely that such a small difference in mean age would affect comparisons between the two surveys. Nevertheless, the slightly lower water intake recorded in the 2000 survey could be explained by the slightly lower mean age. The proportions of water intake coming from various sources are unlikely to be affected by the different durations of the studies. The effect of climatic season was not examined, as previously ${ }^{5}$ no effect was observed.

Values for water content were obtained from current food composition tables. Partly due to the growth in the variety of foods over 20 years, the number of codes was greater in the 2000 survey. One difference was the way squashes were coded, but coding in 2000 was adapted to ensure comparability between surveys. One drawback, which should be addressed in future surveys of water intake, was the inability to code water from the tap differently from bottled water because different codes for tap and bottled water were not available in the food composition tables. This has reduced the accuracy of the estimate of water from public water supplies. While bottled water consumption was negligible in 1980 , recent NDNS data ${ }^{4}$ show that 9\% of 'plain' water was bottled water and the remaining 91\% from the tap, in 11-14-year-olds. In addition, water used to make squashes or hot drinks was very unlikely to have been bottled water. Thus, a maximum of $20 \mathrm{~g}$ of the $225 \mathrm{~g}$ intake from 'water' (Table 1) is likely to have been bottled water and, therefore, not 'consumer-added water' (ie from the household tap), with a possible 5\% error in estimation. Nevertheless, the concept of trying to estimate the amount of water obtained from public water supplies, either in the home (consumer-added water) or from elsewhere (manufacturer-added water), is important in determining fluoride intake from public water supplies. The smaller difference in dental caries experience between fluoridated and fluoride-low areas observed more recently is thought to be due to the 'halo' effect of water fluoridation. ${ }^{25,26}$ The present study supports this hypothesis as manufacturer-added water (which could come from a soft drinks company some distance from the consumer) was a much more important source of water in these adolescents in 2000 than it was in 1980.

The present findings can be compared with results of studies in the USA, Germany and the UK, although differences in data collection methods, definition of water intake and age of the subjects make comparisons fragmentary. The present estimate of total water intake (mean of $1.13 \mathrm{l} \mathrm{d}^{-1}$ ) was much lower than the $2.27 \mathrm{~d}^{-1}$ intake recorded by Heller et al. ${ }^{8}$ for American 11-19-year-olds, $1.74 \mathrm{ld}^{-1}$ recorded by Sohn et al. ${ }^{9}$ for American 1-10-year-old and $1.78 \mathrm{ld}^{-1}$ recorded by Sichert-Hellert et al. ${ }^{12}$ for German 9-13-year-olds. Total water was not recorded in the UK NDNS. ${ }^{4}$ Further studies are needed to clarify reasons for these differences. Only the German study separated water from drinks and foods, yielding estimates of 50\% from drinks, 37\% from foods and 13\% from metabolic water. The proportion coming from foods was higher than in the present study, and we did not include metabolic water. The intake of 'drinking water' recorded by Heller et $a l^{8}\left(718 \mathrm{~g} \mathrm{~d}^{-1}\right)$ was very much higher than the $225 \mathrm{~g} \mathrm{~d}^{-1}$ recorded in the present study, and the difference is likely to be due to differences in definitions. Soft drink consumption recorded in the UK NDNS 4 for $11-14$-year-olds $\left(711 \mathrm{~g} \mathrm{~d}^{-1}\right.$ in boys and $575 \mathrm{~g} \mathrm{~d}^{-1}$ in girls) was much higher than that recorded by us for 11-12-yearolds $\left(291 \mathrm{~g} \mathrm{~d}^{-1}\right)$. However, the intake of plain water recorded in the NDNS ( $91 \mathrm{~g} \mathrm{~d}^{-1}$ in boys and $105 \mathrm{~g} \mathrm{~d}^{-1}$ in girls) was lower than in the present study (225 $\left.\mathrm{g} \mathrm{d}^{-1}\right)$ suggesting differences in definitions, particularly for water in squash. The higher intake of carbonated drinks in the NDNS ( $\left.238 \mathrm{~g} \mathrm{~d}^{-1}\right)$ than in the present study (191 $\left.\mathrm{g} \mathrm{d}^{-1}\right)$ could be due to the difference in age of the subjects. Soft drink consumption recorded for 9-13-year-old Germans ${ }^{12}\left(203 \mathrm{~g} \mathrm{~d}^{-1}\right.$ for boys and $155 \mathrm{~g} \mathrm{~d}^{-1}$ for girls) was lower than our figure $\left(291 \mathrm{~g} \mathrm{~d}^{-1}\right)$, although the German data were average intakes between 1985 and 1999, and soft drink consumption is likely to have increased during this period. Milk consumption recorded in the present study $\left(128 \mathrm{~g} \mathrm{~d}^{-1}\right)$ was lower than that recorded for German adolescents ${ }^{12}\left(203 \mathrm{~g} \mathrm{~d}^{-1}\right.$ in boys and $144 \mathrm{~g} \mathrm{~d}^{-1}$ in girls) and in the UK NDNS ${ }^{4}$ (boys $218 \mathrm{~g} \mathrm{~d}^{-1}$, girls $\left.139 \mathrm{~g} \mathrm{~d}^{-1}\right)$ - some of these differences may be due to time trends. The consumption of tea recorded by the UK NDNS ${ }^{4}\left(75 \mathrm{~g} \mathrm{~d}^{-1}\right.$ in boys and $82 \mathrm{~g} \mathrm{~d}^{-1}$ in girls) was close to the intake recorded in the present study $\left(68 \mathrm{~g} \mathrm{~d}^{-1}\right)$ for slightly younger subjects. There are no data with which to compare our estimate of $676 \mathrm{~g} \mathrm{~d}^{-1}$ (or 59\% of total water intake) coming from public water supplies.

Water intake is sometimes expressed relative to body weight or energy intake. The value of $38 \mathrm{~g} \mathrm{~kg}^{-1}$ body weight per day recorded by Heller et al. ${ }^{8}$ and $49 \mathrm{~g} \mathrm{~kg}^{-1} \mathrm{~d}^{-1}$ (boys) and $43 \mathrm{~g} \mathrm{~kg}^{-1} \mathrm{~d}^{-1}$ (girls) recorded by Sichert-Hellert et al. ${ }^{12}$ were higher than our values of $26 \mathrm{~g} \mathrm{~kg}^{-1} \mathrm{~d}^{-1}$ for boys and $23 \mathrm{~g} \mathrm{~kg}^{-1} \mathrm{~d}^{-1}$ for girls. Likewise, in the present study, water intakes of $139 \mathrm{~g} \mathrm{MJ}^{-1} \mathrm{~d}^{-1}$ for boys and $143 \mathrm{~g} \mathrm{MJ}^{-1} \mathrm{~d}^{-1}$ for girls were considerably lower than the figure of $231 \mathrm{~g} \mathrm{MJ}^{-1} \mathrm{~d}^{-1}$ reported in the German study. ${ }^{12}$

In the present study, the differences in intakes between boys and girls for soft drinks, tea and milk were similar to those given in the NDNS report ${ }^{4}$ for $11-14$-year-olds. Likewise, the increased intake of soft drinks and the decreased intake of milk and hot drinks over time, agrees with data from the USA ${ }^{8}$ and Germany. ${ }^{12}$

The implications of the findings of this study can be considered under three headings: fluoride intake, general nutrition and conduct 
of surveys. There is little information on fluoride intake from all sources and the contribution of these sources to the total fluoride intake. The relative contribution of fluoride ingested from all drinks to total fluoride is estimated to range from $66 \%$ to $94 \%,{ }^{27-29}$ which comes mostly from public water supplies especially in fluoridated areas and tea. Using reported mean fluoride concentrations of different types of drinks given in the literature, ${ }^{30-32}$ the total fluoride intake from all drinks was estimated to be 0.468 and $0.857 \mathrm{mg} \mathrm{d}^{-1}$ for 11-12-year-old Northumbrian adolescents in 2000 and 1980, respectively (Table 3). On a body weight (bw) basis, the mean total fluoride intake from drinks, of these children in 2000 and 1980 were calculated to be 0.010 and $0.022 \mathrm{mg} \mathrm{kg}^{-1} \mathrm{bw} \mathrm{d}^{-1}$, respectively. This indicates a possible considerable reduction in fluoride intake from this main source for adolescents over a 20 year period. These figures are lower than the range of $0.05-0.07 \mathrm{mg} \mathrm{kg}^{-1} \mathrm{bw} \mathrm{d}^{-1}$ which is recommended as optimum level of fluoride intake for children and adolescents. ${ }^{33,34}$

From the general nutritional viewpoint, there must be some concern that milk is being replaced by soft drinks in the diets of these rapidly growing young adolescents. It could also be argued that the apparent substitution of tea by soft drinks could be detrimental to general nutrition. Soft drinks are high in Non-Milk Extrinsic sugars and low in macronurients whereas tea is often consumed with milk and has the additional benefit of its fluoride content. The nutritional intake of these children and changes in their nutrition over 20 years is reported elsewhere. ${ }^{13}$

There have been few other studies of water intake in children and adolescents. The above discussion has shown difficulties in inter-survey comparisons due to major differences in the way water intake is recorded and presented. A particular difficulty has been the way in which 'drinking water' has been presented, which is of special interest to those wishing to estimate fluoride intake. Our method of presenting 'consumer-added' and 'manufactureradded' water is one way of estimating water likely to have come from the public water supply. In future surveys, though, it will be important to distinguish between bottled and plain tap water. There is always the possibility of subjects under-recording water intake (there is likely to be a lesser risk of over-recording), and ways to reduce this and, although on the face of it very difficult, to estimate the validity of water intake should be sought.

This study was funded by a grant (No: RRCC31R) from the NHS Executive (Northern at Yorkshire Region). Further analyses were made possible by grants from the Bradlaw Trust Fund of Newcastle University School of Dental Sciences. The authors are most grateful to the Northumberland Health and Education Authorities, to the staff of the seven schools, and to the children, and their parents and guardians, who participated so cheerfully. The authors are also most grateful to the Occupational Information Unit of the Office of National Statistics, London, for assisting in classifying parental occupations.

Table 3 Estimation of fluoride intake $\left(\mathrm{mg} \mathrm{d}^{-1}\right)$ from 'all drinks' by study, for 11-12-year-old Northumbrian adolescents.

\begin{tabular}{|c|c|c|c|}
\hline \multirow[t]{2}{*}{ Dietary sources } & \multirow[t]{2}{*}{ Fluoride concentration $\left(\mathrm{mg} \mathrm{l}^{-1}\right)$} & \multicolumn{2}{|c|}{ Fluoride intake $\left(\mathrm{mg} \mathrm{d}^{-1}\right)$} \\
\hline & & 2000 & 1980 \\
\hline $\begin{array}{l}\text { Water (drinking water, water } \\
\text { added to dilute non-carbonated } \\
\text { soft drinks, and hot drinks) }\end{array}$ & $1.00^{1}$ & 0.320 & 0.510 \\
\hline Tea (non-diluted) & $1.50^{2}$ & 0.102 & 0.321 \\
\hline Carbonated soft drinks & $0.19^{3}$ & 0.036 & 0.015 \\
\hline Fruit juices & $0.06^{3}$ & 0.004 & 0.000 \\
\hline Milk & $0.05^{4}$ & 0.006 & 0.011 \\
\hline Total & & 0.468 & 0.857 \\
\hline $\begin{array}{l}\text { Total fluoride intake from } \\
\text { drinks per kg body weight }\end{array}$ & & 0.010 & 0.022 \\
\hline \multicolumn{4}{|c|}{$\begin{array}{l}\text { 19assuming water is fluoridated at a level of } 1 \mathrm{mg} \mathrm{FL}^{-1} \text {. } \\
\text { 2assuming an infusion of tea could add } 1.5 \mathrm{mg} \mathrm{FL}^{-1} \text { to the water from which it is made } \\
\text { (reference 29). } \\
\text { 3Reference } 30\end{array}$} \\
\hline
\end{tabular}

Murray J J, Rugg-Gunn A J, Jenkins G N. Fluorides in caries prevention. 3rd ed. Oxford: Butterworth-Heinemann, 1991.

2 Guillemant J, Le H T, Accarie C, du Montcel S T, Delabroise A M, Arnaud M J, Guillemant $S$. Mineral water as a source of dietary calcium: acute effects on parathyroid function and bone resorption in young men. Am J Clin Nutr 2000; 71: 999-1002.

3 Medical Research Council working group report. Water fluoridation and health. London: Department of Health. 2002.

4 Gregory J R, Lowe S. National Diet and Nutrition Survey:Young people aged 4 to 18 years. Volume 1: Report of the diet and nutrition survey. London: The Stationery Office, 2000.

5 Rugg-Gunn A J, Hackett A F, Appleton D R, Eastoe J E, Dowthwaite L, Wright W G. The water intake of 405 Northumbrian adolescents aged 12-14 years. Br DentJ 1987; 162: $335-340$.

6 Ismail Al, Burt B A, Eklund S A. The cariogenicity of soft drinks in the United States. JAm Dent Assoc 1984; 109: 241-245.

7 Chao E S M, Anderson G H, Thompson G W, Hargreaves J A, Peterson R D. A longitudinal study of dietary changes of a sample of Ontario children. II. Food intake. J Can Dent Assoc 1984; 45: 112-118.

8 Heller KE, Sohn W, Burt B A, Eklund S A. Water consumption in the United States in 1994-96 and implications for water fluoridation policy. J Publ Health Dent 1999; 59: 3-11.

9 Sohn W, Heller K E, Burt B A. Fluid consumption related to climate among children in the United States.J Publ Health Dent 2001; 61: 99-106.

10 Tate \& Lyle Speciality Sweeteners. Sucralose Soft Drinks Report. Reading, UK; 2001.

11 Petter L P, Hourihane J 0 , Rolles C J. Is water out of vogue? A survey of the drinking habits of 2-7 year olds. Arch Dis Child 1995: 72:137-140.

12 Sichert-Hellert W, Kersting M, Manz F. Fifteen year trends in water intake in German children and adolescents: results of the DONALD Study. Acta Paediatr 2001; 90: 732737.

13 Fletcher E S, Adamson A J, Matthews J N S, Hackett A F, Mathers J C, Moynihan P J, Rugg-Gunn AJ. Changes in macronutrient intake and BMI in young Northumbrian adolescents over 20 years. BrJ Nutr (submitted).

14 Holland B, Unwin I D, Buss D H. Cereal and cereal products: The third supplement to McCance and Widdowson's The composition of foods (4th Ed). London: Royal Society of Chemistry and Ministry of Agriculture, Fisheries and Food, 1988.

15 Holland B, Unwin I D, Buss D H. Milk products and eggs: The fourth supplement to McCance and Widdowson's The composition of foods (4th Ed). London: Royal Society of Chemistry and Ministry of Agriculture, Fisheries and Food, 1989.

16 Holland B, Unwin ID, Buss D H. Vegetables, herbs and spices: The fifth supplement to McCance and Widdowson's The composition of foods (4th Ed). London: Royal Society of Chemistry and Ministry of Agriculture, Fisheries and Food, 1991

17 Holland B, Unwin I D, Buss D H. Fruit and nuts: The first supplement to McCance and Widdowson's The composition of foods (5th Ed). London: Royal Society of Chemistry and Ministry of Agriculture, Fisheries and Food, 1992a.

18 Holland B, Welsh A A, Buss D H. Vegetable dishes: The second supplement to McCance and Widdowson's The composition of foods (5th Ed). London: Royal Society of Chemistry and Ministry of Agriculture, Fisheries and Food, 1992b.

19 Holland B, Brown J, Buss D H. Fish and fish products: The third supplement to McCance and Widdowson's The composition of foods (5th Ed). London: Royal Society of Chemistry and Ministry of Agriculture, Fisheries and Food, 1993.

20 Chan W, Brown J, Buss D H. Miscellaneous foods: Supplement to McCance and Widdowson's The composition of foods. London: Royal Society of Chemistry and Ministry of Agriculture, Fisheries and Food, 1994.

21 Chan W, Brown J, Lee S M, Buss D H. Meat, poultry and game:Supplement to McCance and Widdowson's The composition of foods. London: Royal Society of Chemistry and Ministry of Agriculture, Fisheries and Food, 1995.

22 Chan W, Brown J, Church S M, Buss D H. Meat, products and dishes: Supplement to McCance and Widdowson's The composition offoods. London: Royal Society of Chemistry and Ministry of Agriculture, Fisheries and Food, 1996.

23 Hackett A F, Rugg-Gunn A J, Appleton D R. The use of a dietary diary and interview to estimate the food intake of children. Hum Nutr:App/ Nutr 1983; 37A: 293-300.

24 Office of Population Census and Surveys. Standard occupational classification, vol 3. London: HMSO, 1990.

25 Kiritsy M C, Levy S M, Warren J J, Guha-Chowdhury N, Heilman J R, Marshall T. Assessing fluoride concentrations of juices and juice-flavored drinks. J Am Dent Assoc 1996; 127: 895-902.

26 Griffin S O, Gooch B F, Lockwood, S A, Tomar, S L. Quantifying the diffused benefit from water fluoridation in the United States. Community Dent Oral Epidemiol 2001 29: 120-129

27 McClure FJ. Fluorine in food - survey of recent data. Pub Health Rep 1949; 64: 10611074.

28 Zohouri F, Rugg-Gunn A J. Sources of dietary fluoride intake in 4 year old children residing in low, medium and high fluoride areas in Iran. Int J Food Sci Nutr 2000; 51 : 317-326.

29 Schamschula R G, Un PS, Sugar E, Duppenthaler J L, Toth K, Barmes D E. The fluoride content of selected foods in relation to the fluoride concentration of water. Acta Physiol Hung 1988; 72: 217-227.

30 Ramsey A C, Hardwick J L, Tamacas J C. Fluoride intake and caries increments in relation to tea consumption by British children. Caries Res 1975: 9:312(Abstr).

31 Darwish I, Toumba K J. A comparison of the fluoride content of children's drinks in the UK and UAE. Caries Res 2002; 3: 203 (Abstr).

32 Food Standards Agency. 1997 Total diet surveystudy - fluoride, bromide and iodine. Food survey information sheet, no 5/00. London: FSA, 2000.

33 Clarkson J J, McLoughlin J. Role of fluoride in oral health promotion. Int Dent J 2000; 50: $119-128$.

34 Pendrys D G. Fluoride ingestion and oral health. Nutr 2001; 17: 979-980. 